\title{
IMMUNE RESPONSES OF DIFFERENT MOUSE STRAINS AFTER CHALLENGE WITH EQUIVALENT LETHAL DOSES OF TOXOPLASMA GONDII
}

\author{
LEE Y.H.* \& KASPER L.H.**
}

\section{Summary:}

Most immunological studies that utilize different strains of inbred mice following $T$. gondii infection fail to compensate for differences in host susceptibility to the size of the parasite innoculum. To address this concern, susceptible C57BL/6 and resistant $\mathrm{CBA} / \mathrm{J}$ mice were orally infected with either an equivalent $50 \%$ lethal dose $\left(L D_{50}\right)$ of brain cysts of the $76 \mathrm{~K}$ strain of T. gondii (15 cysts in C57BL/6, 400 cysts in CBA/J) or the same dose of parasites in each mouse strain. C57BL/6 mice receiving 400 cysts $\left(L_{50}\right.$ of $C B A / J$ mice $)$ died post infection, whereas $\mathrm{CBA} / \mathrm{J}$ mice that received 15 cysts $\left(\mathrm{LD}_{50}\right.$ of $\mathrm{C} 57 \mathrm{BL} / 6$ mice $)$ survived. Parasite loads in the brains and serum Toxoplasmaspecific $\lg G 1$ titers of $L_{50}$-infected $\mathrm{C} 57 \mathrm{BL} / 6$ mice were significantly higher than those in $\mathrm{LD}_{50^{-}}$or 15 cysts-infected $\mathrm{CBA} / \mathrm{J}$ mice, whereas splenocyte proliferation to Toxoplasma antigen and the percentage of $C D 8 \alpha^{+} T$ cells were reduced in $L D_{50}$-infected C57BL/6 mice. In contrast, serum lgG2a and IgM titers, the percentage of $\gamma \delta$ T cells and IFN- $\gamma$ expression of spleen of $L_{50^{-}}$ infected CBA/J mice were higher than those of either 15 cystsinfected $\mathrm{CBA} / \mathrm{J}$ mice or $\mathrm{LD}_{50}$-infected $\mathrm{C} 57 \mathrm{BL} / 6$ mice. These observations demonstrate that the immune response between $\mathrm{LD}_{50}$ infected $\mathrm{C} 57 \mathrm{BL} / 6$ and $\mathrm{CBA} / \mathrm{J}$ mice was more prominent when compared to $\mathrm{C} 57 \mathrm{BL} / 6$ or $\mathrm{CBA} / \mathrm{J}$ mice receiving the same parasite inoculum. These observations would suggest that caution must be excersized in the planning and interpretation of data when the size of the parasite inoculum has not been adjusted for mouse strain.

KEY WORDS : Toxoplasma gondii, toxoplasmosis, lethal equivalence, susceptibility, immune response, mouse.

\section{INTRODUCTION}

T bxoplasma gondii is an obligate intracellular parasite with a global distribution and an extremely broad host range, including birds, mammals and

* Department of Parasitology, College of Medicine, Chungnam National University, 6 Munhwa-dong, Chung-gu, Daejeon 301-131, Korea.

** Department of Medicine (Neurology), Dartmouth Medical School, Lebanon, NH 03756, USA.

Correspondence: Young-Ha Lee.

Tel: +82-42-580-8273 - Fax: +82-42-583-8216.

E-mail: yhalee@cnu.ac.kr
Résumé : RÉPONSE IMMUNITAIRE DE DIFFÉRENTES LIGNÉES DE SOURIS SOUMISES A DES DOSES LÉTALES ÉQUIVALENTES DE TOXOPLASMA GONDII La plupart des études utilisant différentes lignées consanguines de souris infectées par T. gondii ne réussissent pas à compenser les différences de sensibilité des hôtes envers la quantité de parasites inoculée. Face à ce problème, des souris C57BL/6 sensibles et $C B A / J$ résistantes on été infectées par voie orale soit par des équivalents de $50 \%$ de la dose létale $\left(D L_{50}\right)$ de kystes d'origine cérébrale de la souche $76 K$ de T. gondii 115 kystes pour C57BL/6, 400 kystes pour CBA/Jl, soit par une même quantité de parasites chez chacune des lignées de souris. Les souris C57BL/6 qui reçoivent 400 kystes $\left(D_{50}\right.$ des souris $\left.C B A / J\right)$ en meurent, tandis que les souris CBA/J qui reçoivent 15 kystes $\left(D L_{50}\right.$ des souris $\left.C 57 \mathrm{BL} / 6\right)$ survivent. La charge parasitaire cérébrale et les taux sériques d'lgGl spécifiques de Toxoplasma des souris $C 57 \mathrm{BL} / 6$ infectées par la $\mathrm{DL}_{50}$ sont significativement plus élevés que ceux des souris CBA/J infectées par la $D L_{50}$ ou par 15 kystes, alors que la proliferation de splénocytes et le pourcentage de cellules CD8 $\alpha^{+}$T sont plus bas chez les souris $\mathrm{C} 57 \mathrm{BL} / 6$ infectées par la $\mathrm{DL}_{50}$. Par contre, les taux sériques $d^{\prime} \lg G 2 a$ et $d^{\prime} \lg M$, le pourcentage de cellules $\gamma \delta$ T et la réaction splénique en IFN- $\gamma$ des souris CBA/J infectées par la $D_{50}$ sont plus élevés que ceux des souris CBA/J infectées par 15 kystes ou des C57BL/ 5 infectées par la $\mathrm{DL}_{50}$. Ces observations démontrent que la réponse immunitaire des souris $\mathrm{C} 57 \mathrm{BL} / 6$ et $\mathrm{CBA} / \mathrm{J}$ infectées par une $D L_{50}$ est plus prononcée que celle des souris C57BL/6 ou CBA/J recevant le même inoculum de parasites. Ces observations pourraient suggérer que la prudence doit être de mise dans la présentation et l'interprétation des données quand la quantité de parasites inoculée n'a pas été adaptée à la lignée de souris utilisée.

MOTS CLÉS : Toxoplasma gondii, toxoplasmose, dose létale, sensibilité response immune, souris.

humans. Only one species of this parasite has been identified, but there is marked variation in susceptibility, according to its host. Even within the mouse, different inbred strains have markedly different susceptibility to $T$. gondii infection. These susceptibility differences may be due to differences in the virulence of the parasite itself or differences in the genetic make-up of the mice in terms of their immune response (Johnson et al., 2002). The mortality of mouse strains varies widely depending on the parasite strain, size of inoculum, infection route, and gender of the mouse. Earlier studies considered mortality, cytokine production, and parasite burden after challenge infection of susceptible and 
resistant strains of mice with the same or similar doses of T. gondii parasites (McLeod et al., 1989; Suzuki et al., 1995; Deckert-Schluter et al., 1995; Luo et al., 1997; Schluter et al., 1999). There have been no reports in which resistant and susceptible mice have been challenged with a physiologically normalized number of organisms. In order to alleviate the parasite dose dependent bias on the immune response in different genetic backgroud, susceptible $\mathrm{C} 57 \mathrm{BL} / 7$ mice and resistant $\mathrm{CBA} / \mathrm{J}$ mice were infected by the oral route with a $50 \%$ lethal dose $\left(\operatorname{LD}_{50}\right)$ as well as the same dose of parasites in each mouse strain for the particular strain. Following infection, we compared the parasite burden as well as the humoral and cell-mediated immune responses of these two strains of mice.

\section{MATERIALS AND METHODS}

\section{MiCE AND PARASITE STRAINS}

$\mathrm{F}$ Temale inbred $\mathrm{C} 57 \mathrm{BL} / 6$ and $\mathrm{CBA} / \mathrm{J}$ mice were obtained from the Korea Research Institute of Bioscience and Biotechnology, Daejeon, Korea. All mice used were 8-10 weeks old and documented to be specific-pathogen-free animals. They were maintained under approved conditions in our college's animal research facilities. Two strains of $T$. gondii were used. The RH strain was used to prepare Toxoplasma lysate antigen (TLA), and the $76 \mathrm{~K}$ strain was used to infect mice orally.

\section{PARASite CHALlenge OF MiCE}

To determine the $\mathrm{LD}_{50}$ per oral dose of the $76 \mathrm{~K}$ strain of T. gondii, C57BL/6 mice were infected with four, 15 , or 40 brain cysts per mouse, while $\mathrm{CBA} / \mathrm{J}$ mice were infected with 100,400 , or 1,600 brain cysts. There were 20 mice in each group to study mortality, and checked four weeks daily. After determination of $\mathrm{LD}_{50}$ of each mouse, mice were infected with $\mathrm{LD}_{50}$ of parasites into $\mathrm{C} 57 \mathrm{BL} / 6$ or $\mathrm{CBA} / \mathrm{J}$ mice to compare the immune responses between two strains of mice. To compare the immune responses at the same doses of parasites, mice were also infected with $\mathrm{LD}_{50}$ of $\mathrm{C} 57 \mathrm{BL} / 6$ mice into $\mathrm{CBA} / \mathrm{J}$ mice as well as $\mathrm{LD}_{50}$ of $\mathrm{CBA} / \mathrm{J}$ mice into $\mathrm{C} 57 \mathrm{BL} / 6$ mice. Five mice were used in each value at all time point for evaluation of immune responses and parasite burdens at day $0,3,7,14$ and 28 post-infection (PI), respectively. Age- and sex-matched control mice of the same strains were treated with a similar dose of brain homogenate from uninfected mice.

\section{Titration OF SERUM ANTIBODIES BY ELISA}

We did preliminary experiments to set-up the adequate dilution in ELISA system, and then we determined the dilution factors of serum as 1:100. Each well of a 96well plate was coated with TLA $(10 \mu \mathrm{g} / \mathrm{ml})$, and incubated overnight at $4^{\circ} \mathrm{C}$. TLA was prepared according to the protocol outlined by Lee et al. (1999a). After blocking, serum samples were diluted 1:100 in 0.1\% BSA/PBS containing $0.05 \%$ Tween 20 and added $100 \mu \mathrm{l}$ per well. After two hours, HRP-conjugated goat anti-mouse IgG1, IgG2a, or IgM (Southern Biotechnology Associates Inc., USA) was applied. After washing, freshly prepared O-phenylenediamine dihydrochloride was added, and the reaction was stopped by the addition of $4 \mathrm{~N} \mathrm{H}_{2} \mathrm{SO}_{4}$. Optical density was read at $492 \mathrm{~nm}$ using an automatic ELISA reader (Spectra, Molecular Devices, USA).

\section{SPLENOCYTE PREPARATION}

AND PHENOTYPIC ANALYSIS BY FLOW CYTOMETRY

Spleens from mice were homogenized, and erythrocytes were lysed by Tris- $\mathrm{NH}_{4} \mathrm{Cl}(\mathrm{pH}$ 7.2). The splenocytes were washed in RPMI 1640 (Sigma, USA) containing $10 \%$ heat-inactivated FBS, and antibiotics. Splenocyte containing $1 \times 10^{6}$ cells were incubated with either $50 \mu \mathrm{l}$ of FITC-conjugated anti-mouse CD $4, \mathrm{CD} 8 \alpha$, and $\gamma \delta$ monoclonal antibodies (1:100 dilution in $0.1 \%$ BSA/PBS; PharMingen, USA) or isotype-specific control (PharMingen, USA) for 60 minutes at $4^{\circ} \mathrm{C}$. Cells were washed three times in $0.1 \% \mathrm{BSA} / \mathrm{PBS}$ by centrifugation, fixed with $1 \%$ paraformaldehyde and then analyzed by flow cytometry (FACScan, Becton Dickinson, USA). The data were analyzed using the Cell-Quest program (Becton Dickinson).

\section{SPLENOCYTE IN VITRO PROLIFERATION ASSAY}

Splenocytes were dispensed in 96-well culture plates at a concentration of $2 \times 10^{5}$ cells per well in RPMI 1640 containing $10 \%$ FBS. Cells were cultured for 72 hours with or without TLA $(15 \mu \mathrm{l} / \mathrm{ml})$ at $37^{\circ} \mathrm{C}, 5 \%$ $\mathrm{CO}_{2}$. After incubation, the cells were pulsed with $0.5 \mu \mathrm{Ci}\left[{ }^{3} \mathrm{H}\right]$-thymidine (Amersham, Belgium) for $12 \mathrm{hr}$ and harvested onto glass-fiber filters by an automatic cell harvester. $\left[{ }^{3} \mathrm{H}\right]$-thymidine incorporation was assessed by a liquid scintillation counter, and the results were expressed as counts per minute (CPM). Data reported represent the mean \pm standard deviation (SD) of triplicate cultures.

\section{CYTOKINE MRNA EXPRESSION IN TISSUES ASSESSED BY RT-PCR}

Cytokine mRNA expression in brains and spleens of mice was assessed according to the method of DeckertSchluter et al. (1995). Each tissue sample was processed for the isolation of total RNA using an RNAgent kit (Promega, USA). A preparation of CDNA was produced using a starting mixture containing $5 \mu \mathrm{g}$ of total 
RNA, $8 \mu$ of $5 \times$ RT buffer, $4 \mu \mathrm{l}$ of dNTPs, $25 \mu \mathrm{M}$ oligodT20 and $1 \mu$ of AMV reverse transcriptase. The PCR was performed with 2-13 $\mu$ of cDNA reaction mixture containing $10 \times$ polymerase buffer, $250 \mu \mathrm{M}$ dNTPs, $0.4 \mu \mathrm{M}$ of 3'- and 5'-primer, $2.5 \mathrm{U}$ Taq polymerase at $94^{\circ} \mathrm{C}$ for one minute, $57^{\circ} \mathrm{C}$ for one minute and $72^{\circ} \mathrm{C}$ for one minute with Thermal cycler (TaKaRa PCR MP, Japan). The sequences of cytokine-specific primer pairs were as follows: hydroxyphosphoribosyltransferase (HPRT), 3'-GAGGGTAGGCTGGCCTATGGCT-5' and 5'TGGATACAGGCCAGACTTTGTTG-3'; IFN- $\gamma$, 3'CTCATGGAATGCATCCTTTTTCG-5' and 5'ACGCTACACACTGCATCTTGG-3'; IL-10, 3'-TGTCTAGGTCCTGGAGTCCAGCAGACTCAA-5' and 5'CCAGTTTTACCTGGTAGAAGTGATG-3'. After 35 cycling, the PCR products were separated by electrophoresis on $2 \%$ agarose gels. Quantification of mRNA was performed with an imaging densitometer (Gel-Doc, BioRad, USA).

\section{QUANTIFICATION OF TISSUE PARASITE BURDEN BY SOUTHERN BLOT}

Southern blots for the quantification of tissue parasite burden were done according to the procedure described by Burg et al. (1989) and Khan et al. (1998). DNA was prepared from the brains and spleens by homogenization of $100 \mathrm{mg}$ of tissue in $2 \mathrm{ml} 0.1 \mathrm{M} \mathrm{NaCl}$, $0.2 \mathrm{M}$ sucrose, 0.01 M EDTA and $0.3 \mathrm{M}$ Tris ( $\mathrm{pH} 8.0$ ). The solution was then incubated for two hours at $65^{\circ} \mathrm{C}$ after the addition of $10 \%$ SDS and proteinase $\mathrm{K}$ $(100 \mu \mathrm{g} / \mathrm{ml})$. Potassium acetate $(8 \mathrm{M})$ was then added followed by precipitation of the solution at $4^{\circ} \mathrm{C}$ for one hour and centrifugation at 5,000 $\times \mathrm{g}$ for 10 minutes. The aqueous phase was extracted with phenol-chloroform and ethanol precipitated. Oligonucleotide primers used to initiate DNA amplification were complementary to segments of the B1 gene of $T$. gondii (5'-GGAACTGCATCCGTTCATGAG and 5'-TCTTTAAAGCGTTCGTGGTC). DNA was amplified by PCR in a solution containing $10 \mathrm{mM}$ Tris- $\mathrm{HCl}(\mathrm{pH} 8.3)$, $1.5 \mathrm{mM} \mathrm{MgCl}_{2}, 50 \mathrm{mM} \mathrm{KCl}, 200 \mu \mathrm{M}$ of each deoxynucleotide, and $0.4 \mu \mathrm{M}$ of primers. A positive control (DNA directly extracted from tachyzoites of the RH strain) and a negative control (distilled water) were tested for each reaction. We applied the same volume of DNA already adjusted same optical density, so the applied volume of each lane was same in all experiments. The reaction was carried through 35 cycles, each consisting of $60 \mathrm{~s}$ at $94^{\circ} \mathrm{C}, 90 \mathrm{~s}$ at $55^{\circ} \mathrm{C}$ and $60 \mathrm{~s}$ at $72^{\circ} \mathrm{C}$. After migration on a $2 \%$ agarose gel, the PCR product was passively transferred onto a nylon membrane. The membrane was fixed for 15 minutes at $120^{\circ} \mathrm{C}$. Blots were prehybridized at $42^{\circ} \mathrm{C}$ for three hours. For hybridization, a non-isotopic 5'-GGCGACCAATCTGCGAATA-CCACC probe was used. For developing, it was labelled at the end with digoxigenin
(Boehringer Mannheim, Germany). After rinsing, the membrane was hybridized with an anti-digoxigenin antibody labeled with alkaline phosphatase. After further rinsing, the membrane was developed with a chemiluminescent substrate CSPD (Disodium 3-(4methoxyspirofl,2-dioxetane-3,2'-(5'-chloro)tricyclo [3.3.1.1.7.7decan)4-yl) phenyl phosphate; DIG Luminescent Detection Kit, Roche Molecular Biochemicals, Germany), and detected by exposure of X-ray film. Quantification of DNA was performed using an imaging densitometer.

\section{STATISTICAL ANALYSIS}

Statistical evaluations of differences in parasitic loads, antibody titers, proliferation assay, phenotype profiles and mRNA levels were determined by Mann-Whitney $\mathrm{U}$ test of nonparametric-independent method and Student's $t$ test. Differences between the various groups were considered significant when $p$ values were $<0.05$.

\section{RESULTS}

EstABlishment OF THE LD $_{50}$ FOR C57BL/6 (susceptible) AND CBA/J (REsistant) MICE

T To determine the $\mathrm{LD}_{50}$ of $T$. gondii in $\mathrm{C} 57 \mathrm{BL} / 6$ and $\mathrm{CBA} / \mathrm{J}$ mice, groups of female $\mathrm{C} 57 \mathrm{BL} / 6$ and $\mathrm{CBA} / \mathrm{J}$ mice were challenged separately with three different doses of brain cysts. Four weeks after infection, the survival rate of $\mathrm{C} 57 \mathrm{BL} / 6$ mice receiving four cysts was $85.0 \pm 7.1 \%, 47.5 \pm 10.6 \%$ in the group receiving 15 cysts per mouse, and $0.0 \pm 0.0 \%$ for those receiving 60 cysts. The survival rates of $\mathrm{CBA} / \mathrm{J}$ mice after oral administration of 100,400 , and 1,600 cysts per mouse were $100 \pm 0.0 \%, 55.0 \pm 14.1 \%$, and $5.0 \pm$ $7.1 \%$, respectively. Therefore, we determined that the $\mathrm{LD}_{50}$ of the $76 \mathrm{~K}$ strain of $T$. gondii was 15 cysts per susceptible C57BL/6 mouse and 400 cysts per resistant $\mathrm{CBA} / \mathrm{J}$ mouse. In comparison with mortality at the same dose of parasites in each mouse strain, C57BL/6 mice receiving 400 cysts $\left(\mathrm{LD}_{50}\right.$ of $\mathrm{CBA} / \mathrm{J}$ mice $)$ were all dead. In contrast, all $\mathrm{CBA} / \mathrm{J}$ mice receiving 15 cysts $\left(\mathrm{LD}_{50}\right.$ of C57BL/6 mice) survived

\section{PARASITE LOADS IN THE BRAIN AFTER INFECTION WERE HIGHER IN C57BL/6 MICE THAN}

IN CBA/J MICE

As shown in Figures $1 \mathrm{~A}, 1 \mathrm{~B}$ and $1 \mathrm{C}$, the parasite load in the spleen of both mouse strains increased after infection to reach a maximum at day 7 PI, and decreased thereafter. At day 7 PI, LD 50 -infected $\mathrm{C} 57 \mathrm{BL} / 6$ mice had higher numbers of parasites in the spleen in comparison to $\mathrm{LD}_{50^{-}}$or 15 cysts-infected $\mathrm{CBA} / \mathrm{J}$ mice $\left(\mathrm{p}=0.0025\right.$ in $\mathrm{LD}_{50}$-infected $\mathrm{C} 57 \mathrm{BL} / 6$ vs 
A
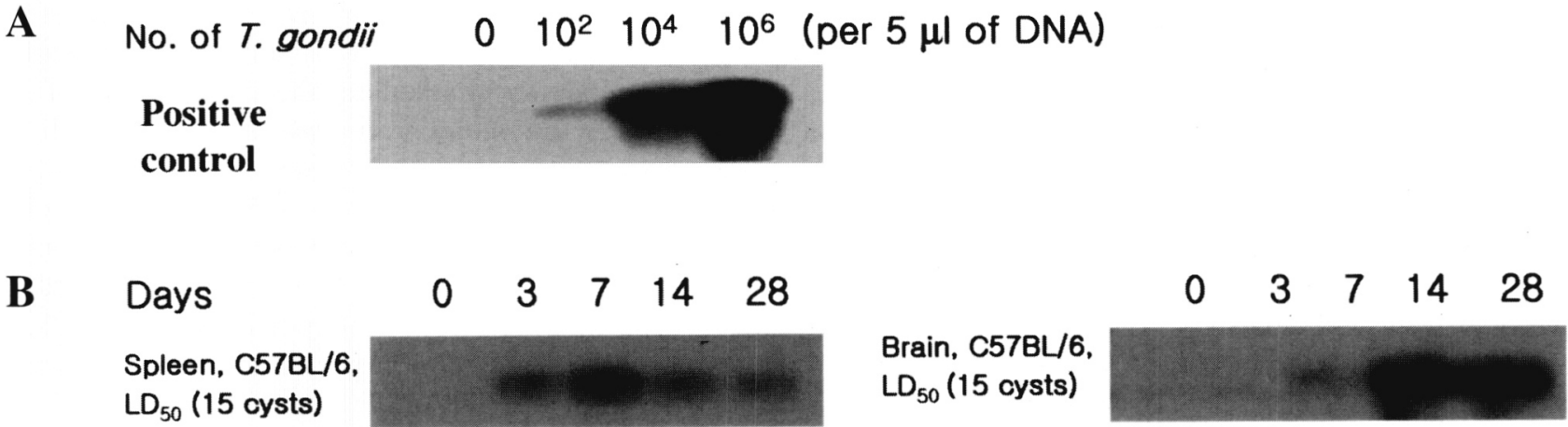

\section{Spleen, CBA/J, $\mathrm{LD}_{50}$ (400 cysts)}

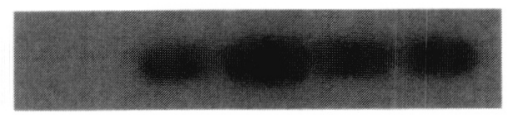

Brain, CBA/J, $\mathrm{LD}_{50}$ (400 cysts)

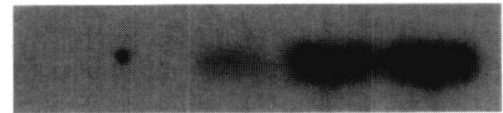

C

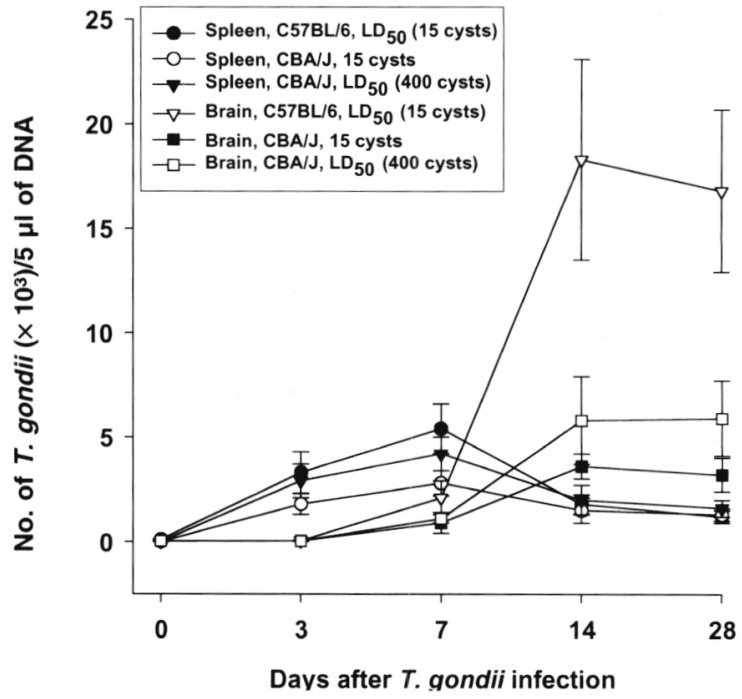

Fig. 1. - Levels of parasite DNA in tissues of $\mathrm{C} 57 \mathrm{BL} / 6$ and $\mathrm{CBA} / \mathrm{J}$ mice orally infected with the $76 \mathrm{~K}$ strain of $T$. gondii. A, T. gondii DNA levels of positive control by Southern blot; B, Southern blot of $T$. gondii DNA levels of the spleens and brains from $\mathrm{LD}_{50}$-infected $\mathrm{C} 57 \mathrm{BL} / 6$ and $\mathrm{CBA} / \mathrm{J}$ mice. $\mathrm{C}$, the kinetics of $T$. gondii $\mathrm{DNA}$ levels of the spleens and brains from $\mathrm{C} 57 \mathrm{BL} / 6$ and $\mathrm{CBA} / \mathrm{J}$ mice orally infected with the $76 \mathrm{~K}$ strain of $T$. gondii. The data are expressed as mean \pm standard deviation (SD) of one of two separate experiments ( $n=5$ for each value at all time point). The experiment was repeated two times with essentially similar results.

15 cysts-infected $\mathrm{CBA} / \mathrm{J}, \mathrm{p}=0.999$ in $\mathrm{LD}_{50}$-infected $\mathrm{C} 57 \mathrm{BL} / 6$ vs $\mathrm{LD}_{50}$-infected $\mathrm{CBA} / \mathrm{J}$ ). The parasite burdens in the spleen of $\mathrm{CBA} / \mathrm{J}$ mice receiving 15 cysts were not significant compared to $\mathrm{LD}_{50}$-infected $\mathrm{CBA} / \mathrm{J}$ mice, except day 7 PI. The parasite burden in the brain of both mouse strains also increased after seven days after infection, and was subsequently maintained at a high level. The parasite burden in the brain was, however, markedly higher in $\mathrm{LD}_{50}$-infected $\mathrm{C} 57 \mathrm{BL} / 6$ mice than in $\mathrm{LD}_{50^{-}}$or 15 cysts-infected $\mathrm{CBA} / \mathrm{J}$ mice at day 14 and 28 PI $(0.0005<\mathrm{p}<0.007)$. The parasite burdens in the brain of $\mathrm{CBA} / \mathrm{J}$ mice receiving 15 cysts were lower than those of $\mathrm{LD}_{50}$-infected $\mathrm{CBA} / \mathrm{J}$ mice at day 14 and $28 \mathrm{PI}$ $(\mathrm{p}=0.0544$ at day $14 \mathrm{PI}, \mathrm{p}=0.0155$ at day $28 \mathrm{PI})$.

\section{DifFERENTIAL PRODUCTION OF IGG ISOTYPE TITERS BETWEEN RESISTANT AND SUSCEPTIBLE MICE}

The IgG1 titer of Toxoplasma-infected C57BL/6 and $\mathrm{CBA} / \mathrm{J}$ mice were similar to that of the uninfected control until day 7 PI. Thereafter, the IgG1 titers of
$\mathrm{LD}_{50}$-infected $\mathrm{C} 57 \mathrm{BL} / 6$ mice increased abruptly compared to $\mathrm{CBA} / \mathrm{J}$ mice at the same time point. At days 14 and 28 PI, IgG1 titers of T. gondii-infected C57BL/6 mice were more than two times higher than those of the $\mathrm{CBA} / \mathrm{J}$ mice (Fig. 2A). IgG2a titers of $\mathrm{LD}_{50}$-infected $\mathrm{C} 57 \mathrm{BL} / 6$ mice were consistent with the uninfected control until day 7 PI and increased thereafter. In contrast, the IgG2a titers of $\mathrm{LD}_{50^{-}}$or 15 cysts-infected $\mathrm{CBA} / \mathrm{J}$ mice significantly increased after infection, and their titers were significantly higher than those of $\mathrm{LD}_{50}$ infected $\mathrm{C} 57 \mathrm{BL} / 6$ mice through experiment period. The IgG2a titers of $\mathrm{CBA} / \mathrm{J}$ mice receiving 15 cysts were lower in $\mathrm{LD}_{50}$-infected $\mathrm{CBA} / \mathrm{J}$ mice at day 14 or 28 PI $(\mathrm{p}=0.0009$ at day $14 \mathrm{PI}, \mathrm{p}=0.581$ at day 28 PI) (Fig. 2B). The IgM titers of uninfected $\mathrm{CBA} / \mathrm{J}$ mice were higher than those of uninfected $\mathrm{C} 57 \mathrm{BL} / 6$ mice $(\mathrm{p}=0.0005)$. The IgM titers of $\mathrm{LD}_{50}$-infected $\mathrm{CBA} / \mathrm{J}$ mice increased significantly after day 3 PI and peaked at day 7-14 PI, whereas $\mathrm{LD}_{50}$-infected $\mathrm{C} 57 \mathrm{BL} / 6$ mice significantly increased after day 7 PI. The IgM titers of $\mathrm{CBA} / \mathrm{J}$ mice receiving 15 cysts were lower titers to $\mathrm{LD}_{50^{-}}$ 
A

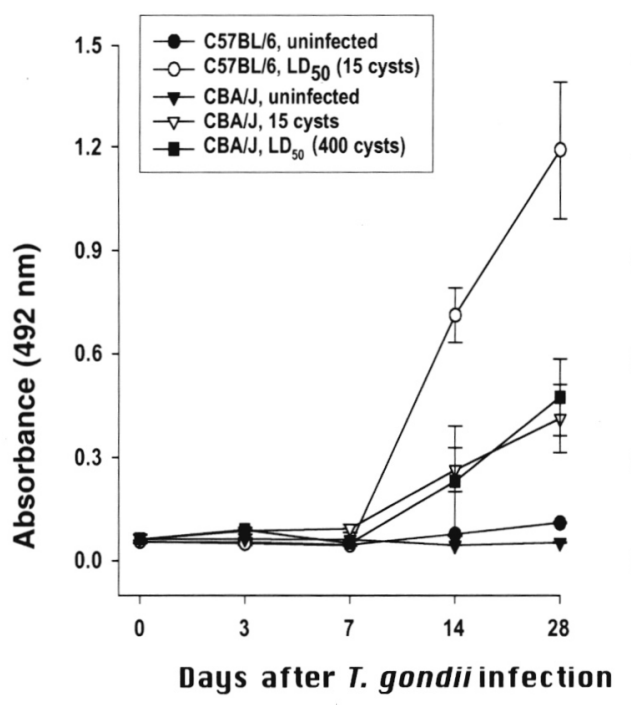

B

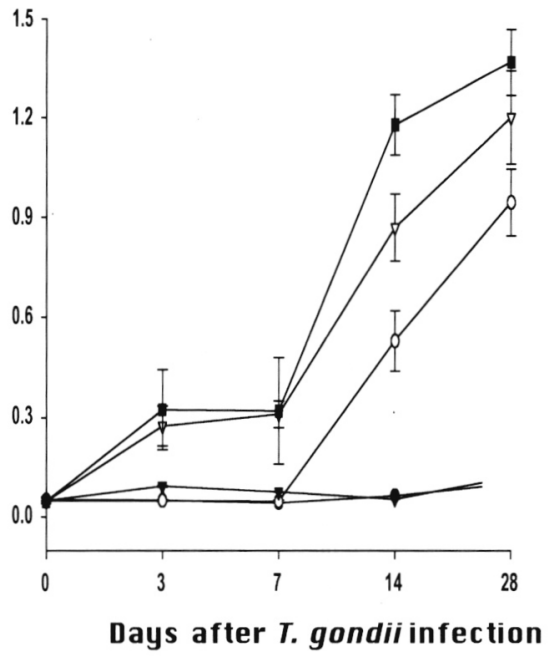

C

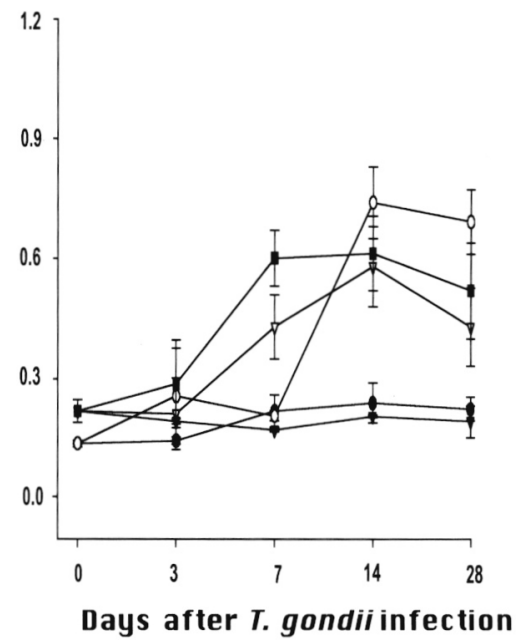

Fig. 2. - Time course of the IgG1 (A), IgG2a (B), and IgM (C) antibody titers of sera from C57BL/6 and CBA/J mice orally infected with the $76 \mathrm{~K}$ strain of $T$. gondii. The data are expressed as mean \pm SD of one of two separate experiments ( $\mathrm{n}=5$ for each value at all time point). The experiment was repeated two times with essentially similar results.

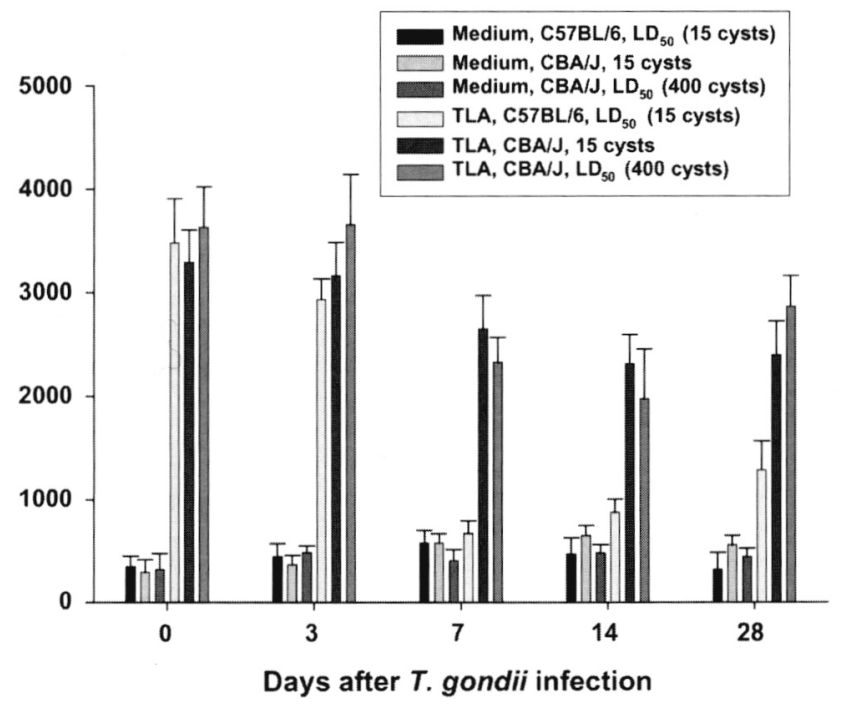

Fig. 3. - Proliferative responses of splenocytes from C57BL/6 and $\mathrm{CBA} / \mathrm{J}$ mice orally infected with the $76 \mathrm{~K}$ strain of $T$. gondii. Spleen cells were cultured in the presence of Toxoplasma lysate antigen for $72 \mathrm{~h}$. The proliferation was assayed by $\left[{ }^{3} \mathrm{H}\right]$-thymidine incorporation. Data are presented as the mean \pm SD of one of two separate experimets $(\mathrm{n}=5$ for each value at all time point). The experiment was repeated two times with essentially similar results.

infected $\mathrm{CBA} / \mathrm{J}$ mice, but not significant differences except day 7 PI ( $p=0.0072$ at day 7 PI) (Fig. 2C).

\section{DIFFERENT PATTERNS OF IN VITRO PROLIFERATION} OF SPLENOCYTES FROM CBA/J AND C57BL/6 MICE

Thymidine incorporation by TLA-treated splenocytes from both mouse strains was significantly increased at day 0 and 3 PI as compared to the medium-treated control group. After day 7 PI, DNA synthesis was markedly depressed in TLA-treated splenocytes obtained from $\mathrm{C} 57 \mathrm{BL} / 6$ mice, whereas DNA synthesis of $\mathrm{CBA} / \mathrm{J}$ mice was not effected. Thymidine incorporation of $\mathrm{CBA} / \mathrm{J}$ mice receiving 15 cysts was similar to that of $\mathrm{LD}_{50}$-infected $\mathrm{CBA} / \mathrm{J}$ mice through experiment $(\mathrm{p}=$ 0.7531) (Fig. 3).

$\mathrm{CD}^{+}{ }^{+} \mathrm{T}$ CELlS ARE DECREASED IN C57BL $/ 6$ MICE, BUT NOT IN CBA/J MICE, AFTER T. GONDII INFECTION

The percentage of $\mathrm{CD}^{+}+\mathrm{T}$ cells from $\mathrm{LD}_{50}$-infected $\mathrm{C} 57 \mathrm{BL} / 6$ mice did not change significantly during the experiment as compared to uninfected $\mathrm{C} 57 \mathrm{BL} / 6$ mice. The percentage of $\mathrm{CD}^{+} \mathrm{T}$ cells in $\mathrm{LD}_{50}$-infected $\mathrm{CBA} / \mathrm{J}$ mice was slightly increased at day 14 PI compared to day $0(\mathrm{p}=0.422)$, and their pattern of $\mathrm{CD}^{+} \mathrm{T}$ cells was similar to $\mathrm{CBA} / \mathrm{J}$ mice receiving 15 cysts (data were not shown). The percentage of $\mathrm{CD} \mathrm{a}^{+} \mathrm{T}$ cells from $\mathrm{LD}_{50^{-}}$ infected $\mathrm{C} 57 \mathrm{BL} / 6$ mice was significantly decreased at day 14 PI compared to day $0(\mathrm{p}=0.0002)$, whereas the percentage of $\mathrm{CD} 8 \mathrm{a}^{+} \mathrm{T}$ cells in $\mathrm{LD}_{50}$ - or 15 cysts-infected $\mathrm{CBA} / \mathrm{J}$ mice was increased at day 14 PI $(0.001<\mathrm{p}<$ 0.0016). The percentage of $\gamma \delta \mathrm{T}$ cells increased abruptly in both strains of mouse after day 3 PI as compared to uninfected controls $(\mathrm{p}<0.0001)$. At day 7 or $14 \mathrm{PI}$, the percentage rise of $\gamma \delta \mathrm{T}$ cells in both strains of mouse was approximately three times higher than in uninfected mice, but the percentage of $\gamma \delta \mathrm{T}$ cells in $\mathrm{LD}_{50}$-infected $\mathrm{CBA} / \mathrm{J}$ mice was higher than in Toxoplasma-infected $\mathrm{CBA} / \mathrm{J}$ mice receiving 15 cysts or $\mathrm{LD}_{50}$-infected $\mathrm{C} 57 \mathrm{BL} / 6$ mice at day 7 or 14 PI $(0.0068<\mathrm{p}<0.1026)$ (Fig. 4). 


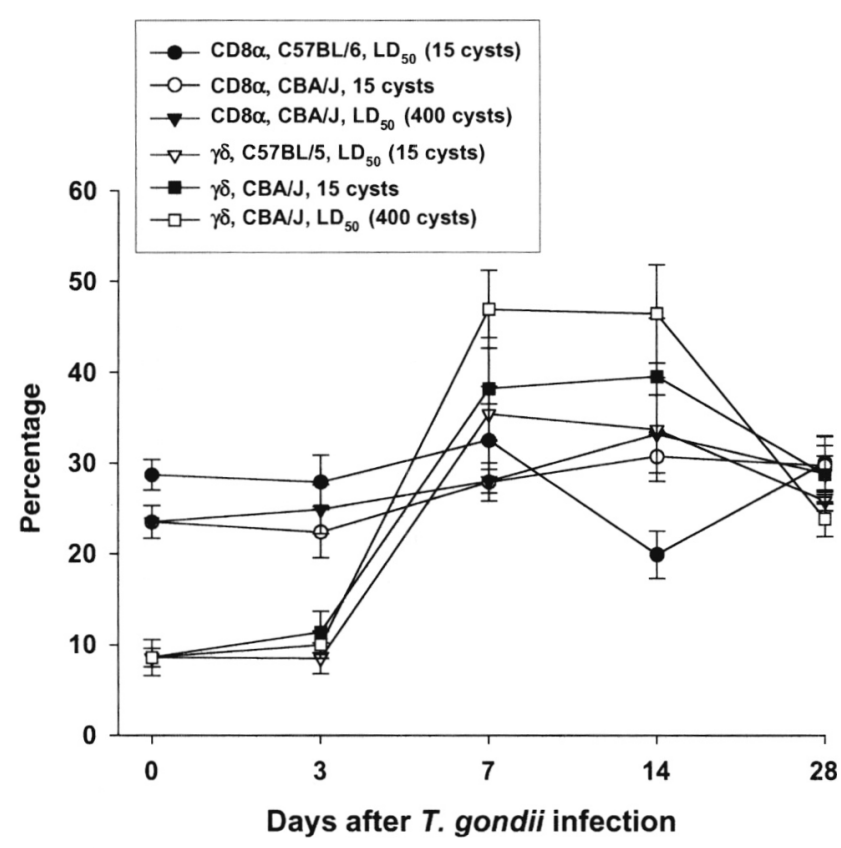

Fig. 4. - The kinetics of phenotypic changes of splenocytes from $\mathrm{C} 57 \mathrm{BL} / 6$ and $\mathrm{CBA} / \mathrm{J}$ mice orally infected with the $76 \mathrm{~K}$ strain of T. gondii. Splenocytes were stained with FITC-conjugated antimouse CD8a, $\gamma \delta$ TCR mAb, and then analyzed by FACScan. Data shown are the mean $\pm S D$ of one of two separate experiments $(n=5$ for each value at all time point). The experiment was repeated two times with essentially similar results.

\section{DIFFERENCES IN IFN- $\boldsymbol{\gamma}$ PRODUCTION BETWEEN RESISTANT AND SUSCEPTIBLE MICE}

The splenic and cerebral HPRT mRNA expression was almost equal during the experimental periods (data was not shown). In Figures 5A and 5B, IFN- $\gamma$ or IL-10 mRNA expression in the spleen and brain of uninfected $\mathrm{C} 57 \mathrm{BL} / 6$ mice was set as 1 at each time point of the experiment. The IFN- $\boldsymbol{\gamma}$ mRNA expression of spleen increased markedly in both strains after infection, and peaked at day 7 PI. IFN- $\gamma$ expression in $\mathrm{LD}_{50^{-}}$ infected $\mathrm{CBA} / \mathrm{J}$ mice was significantly higher than in $\mathrm{LD}_{50}$-infected $\mathrm{C} 57 \mathrm{BL} / 6$ mice before infection, and at days 3 and 7 PI, although the mean increase ratio of IFN- $\boldsymbol{\gamma}$ after infection was higher in $\mathrm{LD}_{50}$-infected C57BL/ 6 mice at day 7 PI (1.0 vs 21.0 in $\mathrm{LD}_{50}$-infected C 57BL/6 mice, 7.5 vs 28.0 in $\mathrm{LD}_{50}$-infected $\mathrm{CBA} / \mathrm{J}$ mice). IFN- $\gamma$ mRNA level in the spleen of $\mathrm{CBA} / \mathrm{J}$ mice receiving 15 cysts was lower to that of $\mathrm{LD}_{50}$-infected $\mathrm{CBA} / \mathrm{J}$ mice. IL-10 mRNA expression in spleen in both strains was similar to that in the uninfected control until day 3 PI. Thereafter, mRNA levels of this cytokine increased significantly in $\mathrm{LD}_{50}$-infected $\mathrm{C} 57 \mathrm{BL} / 6$ mice, whereas only a slight increase was observed in $\mathrm{LD}_{50^{-}}$or 15 cysts-infected CBA/J mice. IL-10 mRNA level in the spleen of $\mathrm{CBA} / \mathrm{J}$ mice receiving 15 cysts
A

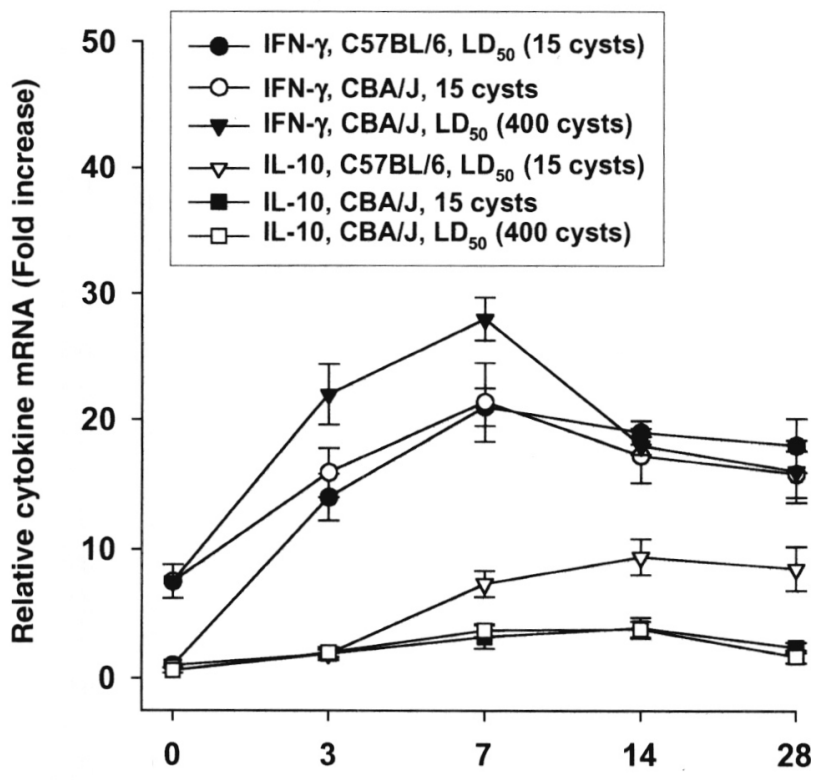

Days after $T$. gondii infection
B

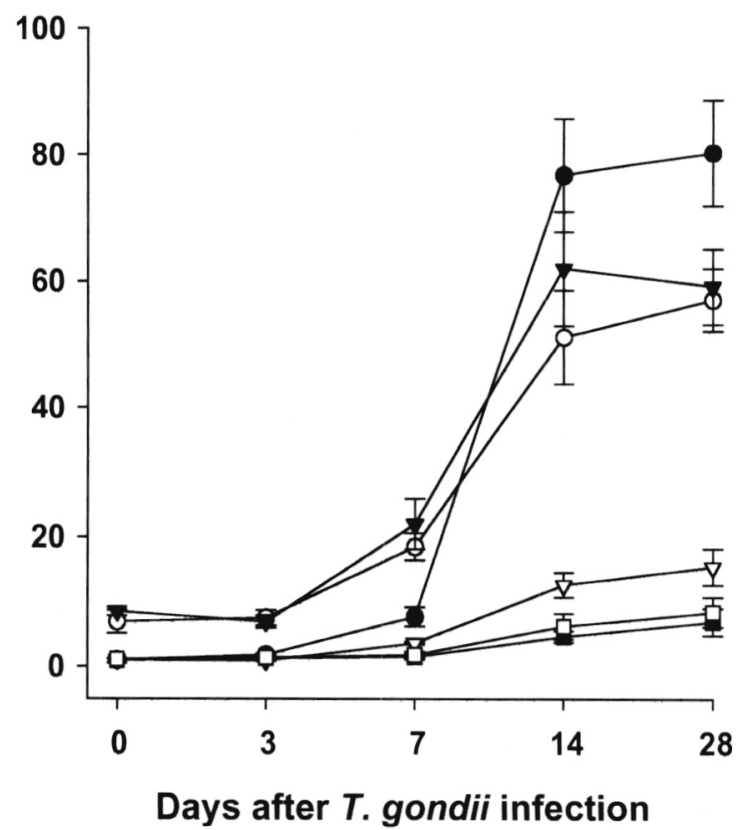

Fig. 5. - Cytokine mRNA levels in spleens (A) and brain (B) from C57BL/6 and CBA/J mice orally infected with the $76 \mathrm{~K}$ strain of $T$. gondii. Data are expressed as relative increase in mRNA levels over the spleen or brain of uninfected $\mathrm{C} 57 \mathrm{BL} / 6$ mice at each time point. IFN- $\gamma$ or IL-10 mRNA expression in the brain and spleen of uninfected C57BL/6 mice was set as 1 at each time point of the experiment. Data shown are the mean \pm SD of one of two separate experiments ( $n=5$ for each value at all time point). The experiment was repeated two times with essentially similar results. 
were similar to that of $\mathrm{LD}_{50}$-infected $\mathrm{CBA} / \mathrm{J}$ mice $(\mathrm{p}=$ 0.9629).

The constitutive IFN- $\boldsymbol{\gamma}$ mRNA level in the brains of uninfected $\mathrm{CBA} / \mathrm{J}$ mice was greater than $\mathrm{C} 57 \mathrm{BL} / 6$ mice. IFN- $\gamma$ mRNA expression in the brains of both strains was not significantly different as compared to uninfected controls until day 3 PI, thereafter a marked increase was observed. At days 14 and $28 \mathrm{PI}$, IFN- $\gamma$ expression in the brain was higher in $\mathrm{LD}_{50}$-infected $\mathrm{C} 57 \mathrm{BL} / 6$ mice than in $\mathrm{LD}_{50}$-infected $\mathrm{CBA} / \mathrm{J}$ mice $(0.0316<p<0.0019)$. IFN $-\gamma$ mRNA level in the brain of $\mathrm{CBA} / \mathrm{J}$ mice receiving 15 cysts were similar to that of $\mathrm{LD}_{50}$-infected CBA/J mice ( $\left.\mathrm{p}=0.8355\right)$. IL-10 mRNA expression in the brain in both strains was similar to that of uninfected control mice until day 7 and increased significantly in $\mathrm{LD}_{50}$-infected $\mathrm{C} 57 \mathrm{BL} / 6$ mice, but not in $\mathrm{LD}_{50^{-}}$or 15 cysts-infected $\mathrm{CBA} / \mathrm{J}$ mice thereafter. IL-10 mRNA level in the brain of $\mathrm{CBA} / \mathrm{J}$ mice receiving 1 cysts were similar to that of $\mathrm{LD}_{50}$-infected $\mathrm{CBA} / \mathrm{J}$ mice $(\mathrm{p}=0.7053)$.

\section{DISCUSSION}

$\mathrm{T}$ his study demonstrates that there is considerable difference in the mortality and immune response between resistant and susceptible mice following oral infection with $T$. gondii and these differences were variable according to dose of parasites. When mice were infected with an equivalent $\mathrm{LD}_{50}$ of the $76 \mathrm{~K}$ strain of $T$. gondii, that is 400 and 15 cysts separately, differences in the immune response were more apparent between resistant and susceptible strains of mice than those mice infected with same dose. This would suggest that an experimental mouse model using an equivalent lethal dose of parasites to compare the immune response is preferable to studies in which mice are infected with the same or similar dose of parasite.

$\mathrm{LD}_{50}$ is widely used to compare the differences among groups in toxicology studies. We utilized the $\mathrm{LD}_{50}$ in order to compare the fundamental differences between two genetically distinct mouse strains. Parasite loads may be related to local immunity or cytopathology. In this study, parasite loads of $\mathrm{C} 57 \mathrm{BL} / 6$ and $\mathrm{CBA} / \mathrm{J}$ mice after $T$. gondii infection were maximal at day 7 PI in the spleens and at day 14-28 PI in the brains. Compared with $\mathrm{LD}_{50}$-infected $\mathrm{C} 57 \mathrm{BL} / 6$ mice, both $\mathrm{LD}_{50^{-}}$or 15 cysts-infected $\mathrm{CBA} / \mathrm{J}$ mice had fewer parasites in the spleen and brain. The patterns of parasite load in the brain and spleen of susceptible and resistant mice infected with $T$. gondii were similar to previously reported by Luo et al. (1997). However, there was no significant difference of parasite burden between $\mathrm{LD}_{50^{-}}$and 15 cysts-infected CBA/J mice. Toxo- plasma-specific IgG2a antibody titers of $\mathrm{CBA} / \mathrm{J}$ mice were significantly greater than those of $\mathrm{C} 57 \mathrm{BL} / 6$ mice. Compared to 15 cysts-infected CBA/J mice, IgG2a titers of $\mathrm{LD}_{50}$-infected CBA/J mice were increased. In contrast to IgG2a, IgG1 antibody titers at days 14 and 28 PI were higher in $\mathrm{C} 57 \mathrm{BL} / 6$ mice than in $\mathrm{CBA} / \mathrm{J}$ mice suggesting an enchanced Th1-type immune response in the susceptible strain (Nguyen et al., 1998). Toxoplasma-specific IgM antibody titers of $\mathrm{CBA} / \mathrm{J}$ mice was higher and increased earlier than those of $\mathrm{C} 57 \mathrm{BL} / 6$ mice. These results further support the importance of the IgM response in host protection against parasite infection (McLeod et al., 1989).

$\mathrm{T}$ cells respond to foreign antigens by proliferation and the synthesis of cytokines, protective immunity against T. gondii is dependent on a strong, cell-mediated, T cell-dependent immune response (Khan et al., 1994; Denkers, 1999; Lee et al., 1999a). In our study, T. gondii infection resulted in a temporary decrease in the percentage of $\mathrm{CD}_{8} \mathrm{a}^{+}$spleen cells in susceptible C57BL/6 mice, but not in resistant $\mathrm{CBA} / \mathrm{J}$ mice. Since $\mathrm{CD} 8^{+}$ $\mathrm{T}$ cells are essential in the generation of protective immunity against toxoplasmosis (Khan et al., 1994), a decreased CD8 ${ }^{+} \mathrm{T}$ cells in Toxoplasma-infected C57BL/6 mice may allow for an increased number of Toxoplasma cysts compared with resistant mice (Brown \& McLeod, 1990; Schluter et al., 1999). In contrast, the percentage of $\gamma \delta$ T cells was markedly increased after infection in both strains of mice. In this study, we showed a more prominent change in the $\gamma \delta \mathrm{T}$ cell proportion in resistant $\mathrm{CBA} / \mathrm{J}$ mice, especially in $\mathrm{LD}_{50^{-}}$ infected $\mathrm{CBA} / \mathrm{J}$ mice, than in $\mathrm{LD}_{50}$-infected $\mathrm{C} 57 \mathrm{BL} / 6$ or 15 cysts-infected $\mathrm{CBA} / \mathrm{J}$ mice. This finding may be related to the role that $\gamma \delta$ T cells play in the early host response to infection with $T$. gondii (Kasper et al., 1996; Lee et al, 1999b). Suppression of lymphocyte DNA synthesis has been demonstrated in some animal models of $T$. gondii infection and in some acutely infected individuals. A variety of factors, including IL-10, IFN- $\boldsymbol{\gamma}$, nitric oxide and parasite factors, may in part be responsible for this down-regulatory event (Candolfi et al., 1994 \& 1995; Khan et al., 1995; Haque et al., 1995). In our study, splenocyte proliferation in response to TLA was markedly depressed in Toxoplasma-infected $\mathrm{C} 57 \mathrm{BL} / 6$ mice from day 7 PI, but not in Toxoplasma-infected $\mathrm{CBA} / \mathrm{J}$ mice. The profile of $\mathrm{T}$ cell cytokine synthesis plays an important role in regulating the immune response and determining relative resistance or susceptibility to $T$. gondii. In our study, IFN- $\gamma$ mRNA expression was significantly increased in the spleen of both mouse strains immediately after $T$. gondii infection. These findings suggest that $T$. gondii infection in mice is predominantly a Th1polarized response (Denkers, 1999). It is interesting that IFN- $\gamma$ mRNA expression in spleen were higher in $\mathrm{LD}_{50^{-}}$ infected $\mathrm{CBA} / \mathrm{J}$ mice than in $\mathrm{LD}_{50}$-infected $\mathrm{C} 57 \mathrm{BL} / 6$ or 
15 cysts-infected $\mathrm{CBA} / \mathrm{J}$ mice, whereas the increase ratio of IFN- $\gamma$ mRNA expression after infection was higher in $\mathrm{C} 57 \mathrm{BL} / 6$ mice. This would suggest that IFN- $\gamma$ plays a major role in murine resistance to $T$. gondii infection (Scharton-Kersten et al., 1996) and that overproduction of type 1 cytokines, in particular IFN- $\gamma$, may lead to immune hyperreactivity in susceptible hosts (Denkers, 1999; Mordue et al., 2001; Mennechet et al., 2002). Therefore, susceptible $\mathrm{C} 57 \mathrm{BL} / 6$ mice may induce more immunopathology than resistant $\mathrm{CBA} / \mathrm{J}$ mice. Also, the increase of IL-10 mRNA expression was particularly pronounced in the spleens of Toxoplasmainfected $\mathrm{C} 57 \mathrm{BL} / 6$ mice as compared to Toxoplasmainfected $\mathrm{CBA} / \mathrm{J}$ mice. This increase indicated that IL-10 plays a major role in protecting the host against an excessive Th1 cytokine response (Suzuki et al., 2000), and the progression of toxoplasmic encephalitis in susceptible mice might be the result of elevated levels of IL-10 in the infected brains of susceptible, but not resistant, mice (Hunter et al., 1994; Khan et al., 1995). Together these observations suggest that $\mathrm{LD}_{50}$-infection of $\mathrm{C} 57 \mathrm{BL} / 6$ and $\mathrm{CBA} / \mathrm{J}$ mice may provide a more definitive measure of immune outcome than mice receiving the same dose. This potential difference should be taken into account when studies are planned to evaluate immune parameters between two or more different strains of inbred mice.

\section{ACKNOWLEDGEMENTS}

T This work was supported by Grant No. 1999-120200-002-2 from the Basic Research Program of the Korea Science \& Engineering Foundation and National Institutes of Health AI19613 and 30000.

\section{REFERENCES}

Brown C.R. \& MCLeod R. Class I MHC genes and $\mathrm{CD}^{+} \mathrm{T}$ cells determine cyst number in Toxoplasma gondii infection. Journal of Immunology, 1990, 145, 3438-3441.

Burg J.L., Grover C.M., Pouletty P. \& Boothroyd J.C. Direct and sensitive detection of a pathogenic protozoan, Toxoplasma gondii, by polymerase chain reaction. Journal of Clinical Microbiology, 1989, 27, 1787-1792.

Candolfi E., Hunter C.A. \& Remington J.S. Mitogen- and antigen-specific proliferation of $\mathrm{T}$ cells in murine toxoplasmosis is inhibited by reactive nitrogen intermediates. Infection and Immunity, 1994, 62, 1995-2001.

Candolfi E., Hunter C.A. \& Remington J.S. Roles of gammainterferon and other cytokines in suppression of the spleen cell proliferative response to concanavalin A and Toxoplasma antigen during acute toxoplasmosis. Infection and Immunity, 1995, 63, 751-756.

Deckert-Schluter M., Albrecht S., Hof H., Wiestler O.D. \& SCHLLTER D. Dynamics of the intracerebral and splenic cyto- kine mRNA production in Toxoplasma gondii-resistant and -susceptible congenic strains of mice. Immunology, 1995, 85, 408-18.

Denkers E.Y. T lymphocyte-dependent effector mechanisms of immunity to Toxoplasma gondii. Microbes and Infection, 1999, 1, 699-708.

Haque S., Haque A. \& Kasper L.H. A Toxoplasma gondiiderived factor(s) stimulates immune downregulation: an in vitro model. Infection and Immunity, 1995, 63, 34423447.

Hunter C.A., Litton M.J., Remington J.S. \& Abrams J.S. Immunocytochemical detection of cytokines in the lymph nodes and brains of mice resistant or susceptible to toxoplasmic encephalitis. Journal of Infectious Diseases, 1994, 170, 939-945.

Johnson J., Suzuki Y., Mack D., Mui E., Estes R., David C., SkAmene E., Forman J. \& MCLeOd R. Genetic analysis of influences on survival following Toxoplasma gondii infection. International Journal for Parasitology, 2002, 32, 179185.

Kasper L.H., Matsuura T., Fonseka S., Arruda J., Channon J.Y. $\&$ KHAN I.A. Induction of $\gamma \delta \mathrm{T}$ cells during acute murine infection with Toxoplasma gondii. Journal of Immunology, 1996, 157, 5521-5527.

Khan I.A., Ely K.H. \& Kasper L.H. Antigen specific CD8 ${ }^{+}$T cell clone protects against acute Toxoplasma gondii infection in mice. Journal of Immunology 1994, 152, 1856-1860.

Khan I.A., Matsuura T. \& Kasper L.H. IL-10 mediates immunosuppression following primary infection with Toxoplasma gondii in mice. Parasite Immunology 1995, 17, 185-195.

Khan I.A., Matsuura T. \& Kasper L.H. Inducible nitric oxide synthase is not required for long-term vaccine-based immunity against Toxoplasma gondii. Journal of Immunology, 1998, 161, 2994-3000.

Lee Y.H., Channon J.Y., Matsuura T., Schwartzman J.D., Shin D.W. \& KASPER L.H. Functional and quantitative analysis of splenic T cell immune responses following oral Toxoplasma gondii infection in mice. Experimental Parasito$\log y, 1999$ a, 91, 212-221.

Lee Y.H., Ely K.H., Lepage A. \& Kasper L.H. Interleukin-15 enhances host protection against acute Toxoplasma gondii infection in T-cell receptor $\alpha-/$ - deficient mice. Parasite Immunology, 1999b, 21, 299-306.

Luo W., Aosai F., Ueda M., Yamashita K., Shimizu K., Sekiya S. \& YANO A. Kinetics in parasite abundance in susceptible and resistant mice infected with an avirulent strain of Toxoplasma gondii by using quantitative competitive PCR. Journal of Parasitology, 1997, 83, 1070-1074.

Mcleod R., Eisenhauer P., Mack D., Brown C., Filice G. \& SPITALNY G. Immune responses associated with early survival after peroral infection with Toxoplasma gondii. Journal of Immunology, 1989, 142, 3247-3255.

Mennechet F.J., Kasper L.H., Racinel N., Li W., Vandewalle A. \& Buzni-Gatel D. Lamina propria $\mathrm{CD}^{+} \mathrm{T}$ lymphocytes synergize with murine intestinal epithelial cells to enhance proinflammatory response against an intracellular pathogen. Journal of Immunolology, 2002, 168, 2988-2996. 
Mordue D.G., Monroy F., La Regina M., Dinarello C.A. \& Sibley L.D. Acute toxoplasmosis leads to lethal overproduction of Th1 cytokines. Journal of Immunology, 2001, $167,4574-4584$.

Nguyen T.D., Bigaignon G., Van Broeck J., Vercammen M., Nguyen T.N., Delmee M., Turneer M., Wolf S.F. \& CouteLIER J.P. Acute and chronic phases of Toxoplasma gondii infection in mice modulate the host immune responses. Infection and Immunity, 1998, 66, 2991-2995.

Scharton-Kersten T.M., Wynn T.A., Denkers E.Y., Bala S., Grunvald E., Hieny S., Gazzinelli R.T. \& Sher A. In the absence of endogenous IFN- $\gamma$, mice develop unimpaired IL-12 responses to Toxoplasma gondii while failing to control acute infection. Journal of Immunology, 1996, $157,4045-4054$

Schluter D., Deckert-Schluter M., Lorenz E., Meyer T., RolLINGER M. \& BOGDAN C. Inhibition of inducible nitric oxide synthase exacerbates chronic cerebral toxoplasmosis in Toxoplasma gondii-susceptible C57BL/6 mice but does not reactivate the latent disease in $T$. gondii-resistant BALB/C mice. Journal of Immunology, 1999, 162, 3512-3518.

Suzuki Y., Yang Q. \& Remington J.S. Genetic resistance against acute toxoplasmosis depends on the strain of Toxoplasma gondii. Journal of Parasitology, 1995, 81, 1032-1034.

Suzuki Y., Sher A., Yap G., Park D., Neyer L.E., Liesenfeld O., Fort M., Kang H. \& Gufwoli E. IL-10 is required for prevention of necrosis in the small intestine and mortality in both genetically resistant $\mathrm{BALB} / \mathrm{c}$ and susceptible C57BL/ 6 mice following peroral infection with Toxoplasma gondii. Journal of Immunology, 2000, 164, 5375-5382.

Reçu le 29 juin 2001 Accepté le 2 octobre 2003 